\title{
Le culte des héros en Europe Centrale, 1880-1945. Edited by Eszter Balázs and Clara Royer.
}

Études et Travaux d'EUR'ORBEM (online), 2019. 286 pp.

\section{Mátyás Erdélyi}

French Research Center in Humanities and Social Sciences, Prague, CZ-110 00 Prague 1, Na Florenci 3, Czech Republic; Institute of History, Research Center for the Humanities, ELKH, H-1097 Budapest, Tóth Kálmán u. 4, Hungary; matyas.erdelyi@cefres.cz

This volume is the outcome of two conferences organized in Budapest in November 2010 and in Paris in November 2011, edited by Clara Royer, maitre de conferences at the Sorbonne University, and Eszter Balázs, assistant professor at the Kodolányi János University. It provides an overview of research on the construction of heroism and the social and political use of hero cults in Central and Eastern Europe. Following current trends in research on heroism, the papers apply interdisciplinary methods in order to uncover the construction and patterns of such cults in the region. The volume emphasizes the construction of heroes between 1880 and 1945, a period of rapid modernization but still somewhat neglected by historical research on the topic. The figures under scrutiny often feed from the tradition of heroism as connected to national independence and wars of independence in Central Europe, with Adam Mickiewicz and Sándor Petöfi being the most notable examples of this kind, but alternative ways of hero cults are also analyzed. The volume is structured into three larger sections that include studies similar in their topic: studying heroes beyond the norms (three articles); the culture of heroes and their use for political mobilization (four articles); "self-made" and alternative heroes (three articles). The case studies cover all regions of Central Europe; the truly interdisciplinary character of the papers is reflected by the use of literary, historical, and sociological approaches.

The volume provides several angles to analyzing the mechanisms of heroism in Central Europe. One of them is to look at how marginalized groups turned to the construction of heroes and used them in their identity discourse, despite the fact that their heroes often formed part of the "official" (national) pantheon of heroes as well. This, of course, directs our attention to the malleability of heroism and the appropriation of historical figures by different social groups and ideologies. An excellent example of the continual re-interpretation of historical heroes is the 
case of Naftali Botwin (chapter by Gerben Zaagsma), a Polish-Jewish communist who was executed for the murder of a policeman in 1925. Botwin's legacy could be altered based on whether he is recalled as a "communist of Jewish descent," a "Jewish communist," or a "Jew" (p. 138). His legacy acquired multiple meanings according to the stance of the interpreter, directing attention to the transnational nature of heroism. Hero cults thus play a key role in identity construction, which is well exemplified by most contributions. Mateusz Chmurski describes the self-heroicizing of literary figures (Karol Irzykowski, Ladislav Klíma, and Géza Csáth) who developed their own imaginary construction of their self in clear opposition to the established national mythology. Eszter Balázs also deals with identity constructions, namely those of artists in the case of literary modernists in Hungary. She argues that the culture of dueling (the metaphorical opposite of the pen) was adapted and transformed by intellectuals not as part of middle-class values but as a distinctive aristocratic feature that was to establish and assure an elite status for modernist writers.

A key feature of the historical construction of heroes is the alternation of continuity and discontinuity in discourses on heroes and heroines. A case in point is the World War I and the political reorganization of Central Europe in its aftermath. The emergence of new multicultural states in post-Habsburg territories created the possibility of a novel (state) discourse on national historical figures, which fundamentally changed the schemes of interpretation. Another important development was the emergence of technological innovations that made it possible to spread the culture of heroism in new ways and to wider social groups. A case in point for the long-term continuity in the construction of heroes is Józef Piłsudski, whose cult was actively fostered from the moment of his death in 1935, including the transfer of his body to the Wawel Cathedral two years later. The pattern was repeated some sixty years later when the Cathedral provided a controversial opportunity to construct a hero cult around the late Lech Kaczyński (chapter by Michel Masłowski). In contrast, the permanent reappropriation of the Uskoks by different ethnic groups and in changing political contexts demonstrates how historical figures and social groups may inspire radically different hero cults (chapter by Daniel Baric).

The most original contribution of the volume, I believe, is to challenge the stereotypical construction of the hero as a male warrior (intellectual or military) through the description of several female figures that indeed became part of national narratives, and, at the same time, these heroes beyond the norms were transformed to fit the accepted patterns of heroism. In this vein, Katarzyna Pabijanek argues that "others" (such as the Jew or the woman) had to be conceptualized in a collective setting and transformed to the liking of the dominant narrative. The Jewish war hero had to "renounce his ethnic and religious otherness," and the female martyr "was deprived of her femininity and made an official virgin" (p. 66). Emilia Platek's 
virginity, in a transgressive act, is seen thus as an invisible armor to protect her from the enemy's attack. Gender analysis plays a crucial role in other contributions as well. Andrea Petó positions Arrow-Cross women and provides a gendered analysis of the culture of heroes in far-right political circles during the World War II. In a similar vein, Dietlin Hüchtker analyzes the life story of three women and describes how women became active agents in identity construction and in specific political movements.

In sum, Le culte des héros en Europe Centrale is a welcome contribution to the field and provides fascinating examples of the construction of heroes from diverse disciplinary approaches. The only shortcoming of the volume might be that the reader sometimes wonders how the highly diverse types of heroes and their conceptualization could fit into one framework, an issue that could have been addressed in a concluding chapter. 